\title{
Kristalina Georgieva-led IMF Prediction, Shocks, and Stability in the West African Monetary Zone
}

\author{
Okechuku Onuchuku ${ }^{1}$, Chukwuemeka Amaefule ${ }^{1 *}$
}

\author{
${ }^{1}$ University of Port Harcourt, NIGERIA \\ *Corresponding Author: chukwuemekamaefule@gmail.com
}

Citation: Onuchuku, O. and Amaefule, C. (2020). Kristalina Georgieva-led IMF Prediction, Shocks, and Stability in the West African Monetary Zone. European Journal of Sustainable Development Research, 4(4), em0136. https://doi.org/10.29333/ejosdr/8406

\section{ARTICLE INFO}

Received: 29 Mar. 2020

Accepted: 22 Jun. 2020

\begin{abstract}
Two compelling structural break models that deal with a known break (Bai 1997, 2010) and unknown common break (Pesaran, 2006) exist in the literature. However, the methodological framework underpinning structural breaks have enjoyed robust attention and filed with highly technical papers. This study considered the Pesaran CD test for cross-section dependence test, Least Squares Dummy Variable (LSDV) to determine heterogeneity in WAMZ, and Panel-ARDL (PMG) with a dummy variable-calibrated known break date to measure the statistical significance of DUM_FDI, DUM_ODA, DUM_IBRD, and Panel ARDL (PMG) without structural dummy-variable breaks. The motivating question becomes how Kristalina Georgieva-led IMF prediction consequently cascades into an intractable long-run effect on the WAMZ system. Due to the demand shocks from COVID-19 pandemic and supply shocks-supply glut from a price war between Saudi Arabia-Russia which has put the global economy into recession. The stability of the global economy is threatened, thus, since FDI, ODA is an integral part of global reinvested earnings (UNCTAD, 2020), hence this study is apt to unravel the impact of structural breaks in WAMZ arising from prior shocks between 1970-2017 from data sourced from World Development Indicators. This study measured how dummy variable $(0,1)$ structural breaks in foreign capital inflows (proxy by FDI, ODA, and IBRD) have long-term impacts in stimulating instability in WAMZ. We represented the dummy variable values 0 and 1; where 1 is structural breakpoints dates and afterward and 0 is used to denote before the structural breakpoints date. From the study, we observed that there exists cross-dependence in WAMZ at $1 \%$ LOS, heterogeneity also exists in WAMZ. Also, the impacts of structural breakpoints on selected macroeconomic indicators are mixed. The study found that the statistical significance of structural breakpoint at 5\% LOS traces the susceptibility WAMZ to the rampaging health-related demand shocks and supply shocks in the long-run. Hence, a recession is likely in WAMZ. The study recommends that the regional government should undertake reforms to consciously diversify their economies and create market fundamental buffers, stimulate productivity and competitive supply frontier with a view to jump-start WAMZ economies from the impact of shocks and disturbances. In addition, provide stabilization funds to mitigate the adverse impact of shock-structural breaks on WAMZ economies.
\end{abstract}

Keywords: Kristalina Georgieva-led IMF, structural breakpoints, WAMZ and foreign investment inflows, selected macroeconomic indicators

\section{INTRODUCTION}

Global capital inflow depends on global reinvested earnings. The global imperativeness of global capital inflows cannot be overemphasized hence the empirical significance of this study to examine how shocks in global capital inflow into WAMZ could capture Kristalina Georgieva-led IMF prediction on the long-run stability on the WAMZ system?

On March 27, 2020, Kristalina Georgieva-led International Monetary Fund (IMF) through its International Monetary Fund and Financial Committee (IMFC) declared that the global economy tending towards recession. The 2020Q1 recession caused by the combined forces of health-crisis and the global oil price slump is worse than the economic meltdown of 2019 (IMF, 2020). The dual consequence of demand and supply shocks largely explains the propensity for the decline in GDP growth for more than two quarters. On March 8, 2020, global oil price hit US\$30pb from US\$ 42.10pb on March 6, 2020. By March 27, 2020Q1 the price of oil has plunged below $\$ 30 \mathrm{pb}$. The plummet in global oil prices caused uncertainty in the global stocks and share indexes across the world. The global markets have reacted negatively to these shocks. Global share performance was affected declining by more than $7 \%$ in the U.S. and $8 \%$ in the London indexes. These shocks could be explained by two major unrelated factors viz; health-related demand shock e.g. COVID-19 and supply shock caused by the inability of countries to scale back (cut back) oil production e.g. Russia-Saudi Arabia price war effect. Jointly, COVID-19 health-related issues and the supply shock introduced unprecedented global problems especially to the developing economies that depend on foreign assistance from abroad. According to 
Worldometer, as of March 29, 2020 there are $+679,082$ cases, $+31,773$ deaths, and 146,352 recovered cases as results of the coronavirus respiratory infections. By June 08, 2020, the numbers of confirmed cases are put at 7,114, 668 and 406.555 deaths. The four worst-hit countries are the US, Brazil, Russia, Spain etc. The US has 2,007,531, Brazil has 691,962 cases, Russia has 476,658 cases, Spain has 2888,630 cases, and UK has 286,194 cases (Worldometer, June 08, 2020). Conversely, the issue of supply glut shocks is rather not new phenomena compared to the health-related COVID-19 demand shocks. The history of Oil prices crash could be traceable to 1979 Iranian revolution that affected global oil supply, 1980s US production glut, 2008 Financial Meltdown, 2011 political unrest in the Middle East e.g. Egypt, 2014 US production glut, etc. The price gyrations of global oil prices send undesirable disturbances to the global economy (UNCTAD, 2020).

\section{Objective of the Study}

The motivating question, therefore, becomes does external shock in foreign capital inflows generates instability in WAMZ? The objectives, therefore, is to determine the heterogeneity in WAMZ. Investigate the impact of dummy-variable structural breakpoints in foreign capital inflows on selected macroeconomic behaviour of WAMZ, and conduct an empirical comparison between structural breakpoint PMG and non-structural breakpoint PMG results.

\section{Research Hypothesis}

The hypothesis for this paper is that an external shock causes instability. Thus, we decomposed the hypothetical statement into viz;

Null Hypothesis: There is structural stability and

Alternative Hypothesis: There are one or two structural breaks.

\section{Study Limitation}

This study focused on selected global capital inflows variables such as FDI, ODA, and IBRD. Other global capital inflows variables include private foreign investment, remittances, etc. Also, COVID-19 caused a decline in global capital inflow base on the fact that global reinvestment earnings plummeted. But, data from COVID-19 were not captured because of the paucity of data. However, we focused on the transmission effect of previous shocks (volatility, fluctuation) experienced in global capital inflow similar to the experiences in the plummet of global capital inflows as COVID-19 disrupted cross-border financing. It is upon the foregoing trajectory we developed our research question.

\section{LITERATURE REVIEW}

According to Anyanwu and Yameogo (2015) the study analyzed the regional heterogeneity in five African regions. The panel OLS and GMM analysis from 1970-2010 found that GDP per capita, trade openness, net foreign aid, political regime, democracy, level of education, and oil production have mixed implication on FDI inflows in five African regions. Specifically, from the study, oil production, a key component of fluctuation, has a positive role in determining the extent of FDI inflow into West Africa. However, base on this findings, oil production positive role to FDI inflow provides this study the nexus and leverage to investigate the impact of FDI inflow and other inflows on the WAMZ.

The model of structural breakpoints typically provides a springboard to evaluate the null hypothesis against the alternative hypothesis, potential risk, and stability of an economy. Structural breaks are inevitable in a policy-induced economy. The history of policy changes, shocks, and regime shifts in the institutional environment e.g. 1987 capital account liberalization policy in West African Monetary Zone (WAMZ), etc cannot be overemphasized. Structural changes such as economic crises, civil war, global oil shock, reforms, and regime changes noticeably occurred in developing economies. Over time, the nature of globalization and drive toward economic integration had resurrected empirical interest on shock (structural breakpoints) effects on cross-country macroeconomic stability. Pertinently, the evidence of demand shock and supply shock occurring simultaneously in 2020Q1 ignites the imperativeness of this study to confirm the impact shock has on WAMZ. By definition, macroeconomic shocks are random, unpredictable, and unexpected events that bring about changes in real economic growth, unemployment, and inflation. Structural breakpoint accounts for policy changes e.g. Structural Adjustment Programme in Africa, Banjul Action Plan, wars e.g. civil crises, economic disturbances e.g. financial crises, Global Meltdown 2008, regime changes e.g. political transition, government policy changes in currency, exchange rate, devaluation, etc. Dynamical changes occurred through e.g. wars, policy changes, and global crises and policy shifts, decomposed into domestic and external changes; are likely to affect economic interactions within a model, thereby reducing the predictive ability of the model (Byrne and Perman, 2006). Significantly, to properly report shocks impact in WAMZ, structural breakpoints $(0,1)$ ought to be factored-in into an econometric model to accurately measure and statistically estimate the significance of $\mathrm{p}$-values performance (shock) on macroeconomic variables in the shock-infested environment.

Thus, every economy is an integral part of the global economy. This paper is motivated by the evidential impact of global oil crash in Q1 of 2020, the health-related COVID 19 pandemic, the supply shock caused by COVID 19 on the WAMZ. For the fact that WAMZ are recipient of foreign assistances. It is therefore imperative to examine the impact the foreign assistances would generate in WAMZ. More so, that foreign assistances are linked to the profit base of the Multinational Enterprises (MNEs). According to the World Investment Report, 2020Q1 reinvested earning, MNE investment, and GVCs are threatened because of the overwhelming impact of COVID-19 on donor countries such as Europe, China, and the U.S, etc. The significance of this study is based on the fact that external (exogenous) shocks have tendencies to translate to the weakened global recession in WAMZ. The shocks and structural breakpoints revolve around the stability questions of developing (recipient) economy. Instability of the developing 
economies is deducible from its weak diversified economic structure and the economic openness which therefore leads to risk and exposes the developing economies to uncertainty. The economics of structural breakpoints is essential because it helps policymakers to determine whether the long-run stability of macroeconomic estimates is attainable under a given economic outlook.

Yang (2017) captured that a time series can have multiple breaks. Baltagi, Feng, and Kao (2015) explain that ignoring structural breaks may lead to inconsistent estimation and invalid inferences (see Leybourne and Newbold, 2003).In this study, we applied a one-at-a-time Bai $(1997,2010)$ structural break in which break dates are known into Panel ARDL to determine the long-term impact of a shock in foreign assistance on WAMZ macroeconomic outlook. Basically, as a point of departure from previous studies, this paper seeks to investigate the impact of shock-calibrated foreign capital on stability in WAMZ. In the wake of Kristalina Georgievaled IMF prediction on global recession, this study raises awareness on the economic danger of shocks from global reinvested earning (a major component of FDI) on WAMZ.

\section{Theoretical Framework}

This thesis revolves around the debate of the impact of shocks on recipient economies generated from fluctuating global capital inflow. COVID-19 affected cross-border financing. The unsettled impact of global capital inflows on the developing economies could be examined by understanding the exposure risk of global capital inflows on the recipient economies. The irreconcilable debates on the impact of global capital inflows and cross-border financing remain fundamental to optimally analyzed the probably causes of recession as predicted by IMF. Thus, accounting for shocks in foreign capital inflow would suffice to provide an overview of the impact of external shocks on the developing economies. The debates on the empirical effect of globalization viz-a-viz cross-border flow of capital (international capital mobility) persist in the literature. These include viz the Orthodox literature which opines that capital movement generates new investment, drives technology growth that improves efficiency, and stimulates growth. The Dependency literature posits that capital movement causes underdevelopment. Dependency literature is an idea of the mix of structuralism model which revolves around the centre-periphery framework analysis. The Neoclassical counterrevolution literature also holds that open economies' interaction underpins growth and development. They contend that policy administrative changes cause distortions in developing economies which could be mitigated by an economic system devoid of government interferences. The neoclassical argument favour economic openness (McKinnon and Shaw, 1973). These literature set out sound debates on the empirical significance of capital flow. Capital movement is believed to reduce the cost of capital, increase investment, and raise output (Summers, 2000).

\section{Empirical Review}

Ogbonnaya and Otta (2018) adopted Lee and Strazicich (2003) model for data covering 1970 -2015, the study found evidence to accept the alternative hypothesis that structural breaks affect macroeconomic variables in Nigeria. The study concludes that regime-switching models for conducting a time series models. Raheem and Olabisi (2018) in x-raying the impact of asymmetric and breaks in Oil price-output growth from 1986-2017 in 10 selected countries. The study employed nonlinear ARDL and found that (i) without accounting for breaks asymmetry operates in net oil exporters only in both short-term and long-term (ii) adjusted break model found robust measures of oil price and growth fluctuation.

Chang and Perron (2017) in a test to determine structural change in the Consumer Price Index (CPI) of the G7 countries in the unit root process (Null Hypothesis) and fractional unit root test (Alternative Hypothesis). Thus, monthly seasonally adjusted CPI series were obtained from the OECD main economic indicator. The study found an alternative method efficient to capture structural changes in CPI.

Clemente, Gadea, Montanes, and Reyes (2017) examined structural breaks, inflation, and interest rates in G7 countries using a common unit root/co-integration approach to revisits and verify the Fisherian effect for G7 countries. From the Bai-Perron structural break model reveals the existence of structural changes in the Fisher equation, The study concludes that limited evidence exists on the transmission coefficient of the Fisher effect on expected inflation rates to nominal interest rates.

Cho and Vogelsang (2017) analyzed structural change tests on a weakly dependent time series regression. Two types of structural change were considered viz full structural change and partial structural change. Thus, the fixed- $b$ theory was developed under HAC estimators which gave room for fixed- $b$ approximation for the test statistics. The study concludes that (i) when break date is known, the fixed $b$ limits of the statistics depend on (a) break fraction (b) bandwidth tuning parameters (c) Kernel and (ii) when break date is unknown (a) supermum (b) mean (c) exponential Wald statistics are generally employed to test the presence of structural break. Yang (2017) addresses the issue of consistency of trend shift breakpoint estimators in the presence of an underspecified break figures. The study found that in an underspecified break figures, there is no convergence between trend shift breakpoint estimator and the time break points Sengupta (2017) proposed a break-date estimator that would determine the location of the breakpoint. In a study to test for U.S budget spillover and interdependencies in fiscal policy for the period covering 1960-2011. The Sup LR test statistic was employed. The test rejects the Null Hypothesis of no break in budget spillovers. Overall spatial dependence in budget expenditure is found to have increased post-break.

Nejad, Jahantigh, and Rahbari (2016) studied price risk and Tehran stock exchange returns within the period covering 20032014. The study indicates a long-term relationship between oil price risk and Tehran stock market returns. Three structural break model adopted in this study include viz; Gregory and Hansen, Saikkonnen and Lutkepohl, and Johansen trace test.

Gadea, Gomex-Losco, and Montanes (2016) examined the presence of a structural change in a long-term perspective on the relationship between oil prices and the US economy. In a full period multivariate analysis, the study found that (i) structural change does not occur between changes in oil prices and GDP growth (ii) within subperiods the study found the existence of structural breaks in the multivariate framework between oil prices and GDP growth. The study employed time-varying VAR so investigate the 
rationale for the decline of the Oil price shock on GDP growth overtime. The study also identified a negative effect is evident in GDP growth in the time of large oil price increases.

Baltagi, Feng, and Kao (2015) in a heterogeneous panel accommodating structural breaks and cross-sectional dependence study. The study extended the Bai $(1997,2010)$ for known and Pesaran $(2006)$ for unknown common breaks in the slopes. Specifically, the CCE estimators followed Pesaran (2006) mechanism. The study found that the CCE estimator has the same asymptotic distributions as if the true change points were known. The study, however, could not answer the question of structural breaks.

Kapetanois and Tzavalis (2007) built a stochastic and endogenously defined-shock model to determine the size and timing of breaks in stochastic changing agent decision. In testing the Oil-macroeconomy relationship, Kapetanois and Tzavalis (2007) observed that the first Oil shock at the end of 1973 caused a tremendous effect on economic activity. Oil price shock afterward has had a positive long term effect o the slope of the Oil-macroeconomy relationship.

Gylnn, Perera, and Verma (2007) study accounted for unit root test accounting for the possibility of structural breaks. This study focused on the Indian dates from 1950-2005. The study, therefore, rejects that unit root null hypothesis for GDP in both one and two breaks models at 5\% LOS. The GDP data supports Perron's (1989) findings that failure to allow for existing breaks leads to bias, as well as introduces the ability to reject a false unit root null hypothesis.

Westerlund (2006) in a Lagrange multiplier environment studies the existence of solvency of the current account. The study found that in a model with incorporation of a break there exist long-run relationships (cointegration) between savings and investment.

\section{METHOD OF STUDY}

The stability of the macroeconomic coefficient is an important component in econometric modelling. It aids policymaking. The structural break test provides a robust framework to determine the stability of empirical results. Econometric modelling without adequate accommodation for structural breaks could lead to the breakdown of key conditions underlying the result. Initially, structural break analyses could be traceable to Chow (1960). Chow (1960) is a test of whether the true coefficients in two linear regressions of different data set are proportional. It is used to define known structural breakpoints in an F-test framework such as given,

$$
Z_{t}=\left\{\begin{array}{c}
0, t=1,2, \ldots, T_{1} \\
1, t=T_{1}+1, T_{2}+2, \ldots T
\end{array}\right.
$$

Overtime structural break models have been developed to accommodate significant changes in time-series analyses. The structural break model could be viz exogenous structural breaks, endogenous structural breaks, Non-linear breaks, and GLS detrending, multiple structural breaks. The various model classification could be decomposed into Quandt Likelihood Ratio (QLR) test is applied to determine unknown structural breakpoints analysis, however under conditions of $\mathrm{F}$ test trimming method; Others include the Perron (1997) innovational outlier (IO) and additive outlier (AO) models, the Zivot- Andrew (1992) approach, Lumsdaine and Papell (1997) models, Perron and Vegelsang (1992), Perron (1989) and Bai and Perron (1998, 2003) which thus provides the framework for structural break model in which some, but not all, of the model parameters, are allowed to break at $\mathrm{m}$ possible breakpoints;

$$
y_{t}=x_{t}^{\prime} \beta+z_{t}^{\prime} \delta_{j}+\mu_{t} ; t=T_{j-1}+1, \ldots, T
$$

Where regressands $y_{t}$ is modelled as a function of $X_{t}$ and $Z_{t}$ time-invariant and variant regressors. The assumption that underlying economic events remain constant across the entire period is relaxed in the structural breakpoint model in equation 1.

Before delving into result presentation it is imperative we explicitly state the hypothesis of this study. They are viz;

Null Hypothesis: There is structural stability and

Alternative Hypothesis: There are one or two structural breaks.

The p-values enable us to accept or reject the null hypothesis. The assumption is that any external shocks e.g. demand shock or supply shock or policy-induced would affect economic relationships in the long-run. In this study, we considered the PMG ARDL approach based on the panel framework in estimating long-run economic outcomes. The study of structural breaks is inevitable in macro-econometric modelling due to structural changes or regime shifts such as systemic shocks e.g. oil price fluctuations, political shocks, and economic and institutional changes.

\section{Result Presentation}

In the appendix, visual representations of the hypothesized variables were carried out. The graphical illustration shows that there exists a trend in the variables. Hence, we differenced the data accordingly. Also, the descriptive statistics of the variables data for each country were conducted. The data showed a mixed kurtosis (see appendix). The implication of the graphical analyses is the first to determine the impact of foreign capital inflows on the West African Monetary Zone. 
Table 1. Structural Breaks Unit Root Test and Optimum Lag Length by Variable

\begin{tabular}{|c|c|c|c|c|c|c|c|c|c|}
\hline Country & Evaluation Test & LnRGDP & LnTRD & Ln $M L T$ & $\operatorname{Ln} T R B$ & LnFDI & $\operatorname{LnODA}$ & LnIBRD & LnPOP \\
\hline \multirow{2}{*}{ The Gambia } & Optimum lag length & 1 & 1 & 1 & 1 & 2 & 1 & 1 & 4 \\
\hline & Structural Break Date Unit test & 1991 & 1997 & 1981 & 1997 & 2013 & 1997 & 2007 & 1987 \\
\hline \multirow{2}{*}{ Ghana } & Optimum lag length & 1 & $2^{*}$ & 1 & $2^{\star}$ & 1 & 2 & 1 & 4 \\
\hline & Structural Break Date Unit test & 2003 & 1982 & 1984 & 1982 & 2006 & 1990 & 2005 & 1987 \\
\hline \multirow{2}{*}{ Nigeria } & Optimum lag length & 2 & 1 & 3 & 1 & 2 & 1 & 2 & 4 \\
\hline & Structural Break Date Unit test & 1981 & 1984 & 1992 & 1984 & 2004 & 2011 & 1987 & 1988 \\
\hline \multirow{2}{*}{ Sierra Leone } & Optimum lag length & 1 & 1 & 1 & 1 & 3 & 1 & 1 & 4 \\
\hline & Structural Break Date Unit test & 2000 & 2009 & 2009 & 2009 & 2010 & 1999 & 2006 & 1998 \\
\hline \multirow{2}{*}{ Liberia } & Optimum lag length & 1 & 1 & 2 & 1 & 1 & 1 & 2 & 4 \\
\hline & Structural Break Date Unit test & 2009 & 2006 & 1990 & 2006 & 2009 & 2010 & 2006 & 1992 \\
\hline \multirow{2}{*}{ Guinea } & Optimum laglength & 1 & 1 & 1 & 1 & 1 & 1 & 1 & 4 \\
\hline & Structural Break Date Unit test & 2005 & 2013 & 2013 & 2013 & 2012 & 2011 & 2011 & 1992 \\
\hline
\end{tabular}

Source: Author's computation from Eviews 9

\section{GRAPHICAL ANALYSES}

To achieve objective one, this focused on determining the level of heterogeneity in WAMZ. We adopted the Least Squares Dummy Variable (LSDV) model. Thus, the baseline model for LSDV is obtained from Greene (2008, p. 287), given as

$$
y_{i}=X_{i} \beta+D_{i} \alpha+\varepsilon
$$

So, we adapted model 3 with modification based on the expanded model is given by Gujarati and Sangeetha (2008, p. 659) model for the study of four heterogeneous companies. In fact, in this thesis, we assumed that the intercepts and the slope coefficient are not different for the cross-sectional analyses. Hence, we account for heterogeneity in intercept and slope following LSDV outcomes.

$$
Y_{i t}=\alpha_{i}+\alpha_{2} D C_{2 i}+\alpha_{3} D C_{3 i}+\alpha_{4} D C_{4 i}+\beta_{2} X_{2 i}+B_{3} X_{3 i}+\mu_{i}
$$

Secondly, based on the Hausman test, we adopted the PMG framework. We obtained two sets of results from PMG namely PMG without structural breakpoints and PMG with structural breakpoints (see Table 10). We modified PSS (1998) PMG estimator model by incorporating structural breakpoints. Table 1 shows evidence of the structural breakpoint in WAMZ. The structural break unit test was obtained through the Bai-Perron test $(1998,2003)$ of $L+1$ vs. $L$ sequentially determined breaks. Bai-Perron test is used (i) to determine the stationarity level of time series data in concert to avoid spurious and misleading results (ii) to identify structural breaks in the WAMZ system. The import of structural break unit root test helped us to account for seasonal variation that might occur in the data which could distort the required information in the variables of selected TSD. The dummy variables (DUMV) are represented by $1=$ structural breakpoints year and after, and $0=$ before the structural breakpoints; were imposed on the models. The DUMV $(1,0)$ was constructed alongside the breakpoint obtained from the structural break unit root test.

The structural breaks obtained for Table 1 was conducted for each model, which illustrates that multiple breakpoints exist for WAMZ. The existence of multiple breakpoints necessitated further test, hence we adopted the command in Eviews 9 as <show log (GDP) enter> then select <structural break unit root test> in the dialog. From the command, single SBP (structural breakpoint) was obtained that were employed for the construction of dummy variables (DUMV) (see Table 1).

The purpose of Table 1 is to justify the foundation for incorporating DUMV into our models. Obviously, from Table 1 the impact of structural breakpoints cannot be assumed away in investigating the impact of exogenous inflows on the macroeconomic outcomes.

Bai and Perron (1998) idea on structural breakpoint is important because the assumption that econometric models between variables remain constant across the entire period is unattainable. This is deservedly so because there are scenarios where dynamism in exogenous global factors not captured in the model causes changes or deviations in the underlying philosophy guiding the estimated relationship expressed between the regressands and regressors. The structural break model captures these cases by incorporating sudden, permanent changes in the parameters of the models. Structural breakpoints are fully captured in equations.

\section{Model Specification}

Hence, ARDL was modified into PMG model by PSS $(1998$, p.5) given as;

$$
\Delta y_{i}, t=\emptyset_{i} E C_{i}, t+\sum_{j=0}^{q-1} \Delta X_{i}, t-j^{\prime} \beta_{i}, j+\sum_{j=1}^{p-1} \gamma_{i}, j^{*} \Delta y_{i}, t-j+\varepsilon_{i}, t
$$

Where

$$
E C_{i}, t=y_{i}, t-1-X_{i}, t^{\prime} \theta
$$

The Pooled Mean Group (otherwise called Panel ARDL) is used to determine the effect of lag effects or an autoregressive structure of a given economic behaviour. The PMG model is a Panel study estimator. This study employed the PMG because of the 
Table 2. RGDP = f(FDI, ODA, DUMV)

\begin{tabular}{|c|c|c|c|c|c|}
\hline \multirow[b]{2}{*}{ Variables } & \multicolumn{2}{|c|}{ PMGWD } & \multicolumn{2}{|c|}{ LSDV } & \multirow[t]{2}{*}{ LSDV intercept } \\
\hline & coeffic. & Prob & coeffic. & Prob & \\
\hline LnFDI & 0.14593 & 0.0002 & 0.072721 & 0.0007 & \\
\hline LnODA & 0.08572 & 0.0379 & -0.005054 & 0.7449 & \\
\hline DUM_FDI & 0.34654 & 0.0001 & & & \\
\hline DUM_ODA & -0.31662 & 0.0001 & & & \\
\hline LnPOP & 1.51855 & 0.0001 & 1.87784 & 0.0001 & \\
\hline$C$ & -0.80118 & 0.0001 & -3.09751 & 0.0001 & \\
\hline DC2 & & & -1.05095 & 0.0001 & -4.14846 \\
\hline DC3 & & & -1.65818 & 0.0001 & -4.75569 \\
\hline DC4 & & & -0.79549 & 0.0001 & -3.89300 \\
\hline DC5 & & & -0.57611 & 0.0001 & -3.67362 \\
\hline DC6 & & & -0.79958 & 0.0001 & -3.89709 \\
\hline cointeQ01 & -0.2843 & 0.0001 & & & \\
\hline $\mathrm{D}(\mathrm{LnFDI})$ & -0.0374 & 0.0001 & & & \\
\hline $\mathrm{D}($ LnODA $)$ & 0.0295 & 0.3037 & & & \\
\hline D(DUM_FDI) & -0.0104 & 0.8031 & & & \\
\hline D(DUM_ODA) & 0.0775 & 0.0001 & & & \\
\hline $\mathrm{D}(\mathrm{LnPOP})$ & 7.4385 & 0.32101 & & & \\
\hline Adjusted R. & & & 0.9561 & & \\
\hline F-statistic & & & 564.6632 & 0.00001 & \\
\hline
\end{tabular}

where PMGWD: Pooled Mean Group with Dummy Variable Source: Eviews 9

nature of data being evaluated. Hence for the fact, the WAMZ is a group study involving The Gambia, Ghana, Liberia, Sierra Leone, Nigeria, and Guinea. It is for the freogoing imperativeness we employed PMG estimator as defined below.

Thus, models (7) - (12) were respecified from models (5) and (6) based on the variables considered for this study. Therefore, the models (7) - (12) would provide a robust model on which data is collected and estimated.

Respecification of PMG model to Accommodate Structural Breakpoints Dummy Variables

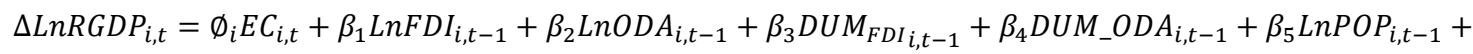

$$
\begin{aligned}
& \lambda_{i} D G D P_{i, t-1}+\varepsilon_{i, t} \\
& \text { where } E C_{i}, t=\operatorname{LnGDP} P_{i}, t-1-X_{i}, t^{\prime} \theta \\
& \Delta L n R G D P C_{i, t}=\emptyset_{i} E C_{i, t}+\beta_{1} L n F D I_{i, t-1}+\beta_{2} L_{n I B R D_{i, t-1}}+\beta_{3} D U M_{-} F D I_{i, t-1}+\beta_{4} D U M_{-} I B R D_{i, t-1}+\beta_{5} \operatorname{LnPOP_{i,t-1}}+ \\
& \lambda_{i} D G D P_{i, t-1}+\varepsilon_{i, t} \\
& \text { where } E C_{i}, t=\operatorname{LnGDP}, t-1-X_{i}, t^{\prime} \theta \\
& \Delta L n R G D P P C_{i, t}=\emptyset_{i} E C_{i, t}+\beta_{1} L n F D I_{i, t-1}+\beta_{2} L n O D A_{i, t-1}+\beta_{3} D U M_{-} F D I_{i, t-1}+\beta_{4} D U M_{-} O D A_{i, t-1}+\beta_{5} L n P O P_{i, t-1}+ \\
& \lambda_{i} D T R D_{i, t-1}+\varepsilon_{i, t}
\end{aligned}
$$

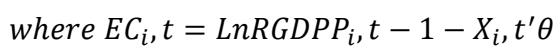

$$
\begin{aligned}
& \Delta L n R G D P P C_{i, t}=\emptyset_{i} E C_{i, t}+\beta_{1} L n F D I_{i, t-1}+\beta_{2} L n I B R D_{i, t-1}+\beta_{3} D U M_{-} F D I_{i, t-1}+\beta_{4} D U M_{-} I B R D_{i, t-1}+\lambda_{i} D M L T_{i, t-1}+\varepsilon_{i, t} \\
& \text { where } E C_{i}, t=L n M L T_{i}, t-1-X_{i}, t^{\prime} \theta \\
& \Delta L n M L T_{i, t}=\emptyset_{i} E C_{i, t}+\beta_{1} L n F D I_{i, t-1}+\beta_{2} L n I B R D_{i, t-1}+\beta_{3} D U M_{F D I i, t-1}+\beta_{4} D U M_{I B R D i, t-1}+\lambda_{i} D M L T_{i, t-1}+\varepsilon_{i, t} \\
& \text { where } E C_{i}, t=L n M L T_{i}, t-1-X_{i}, t^{\prime} \theta \\
& \Delta \operatorname{LnTRB} B_{i, t}=\emptyset_{i} E C_{i, t}+\beta_{1} L n F D I_{i, t-1}+\beta_{2} L n O D A_{i, t-1}+\beta_{3} D U M_{-} F D I_{i, t-1}+\beta_{4} D U M_{-} O D A_{i, t-1_{3}}+\lambda_{i} D T R B_{i, t-1}+\varepsilon_{i, t} \\
& \text { where } E C_{i}, t=\operatorname{LnTR} B_{i}, t-1-X_{i}, t^{\prime} \theta
\end{aligned}
$$

Where RGDPPC $=$ Real Gross Domestic Product Per Capita, RGDP $=$ Real Gross Domestic Product, FDI $=$ Foreign Direct Investment, $\mathrm{ODA}=$ Official Development Assistance, $\mathrm{MLT}=$ Multilateral Trade (Merchandise Export within region), IBRD = International Bank for Reconstruction and Development loans, $T R B=$ Trade Robustness, $\mathrm{POP}=\mathrm{Population}$, and TRD = Trade, EC= speed of adjustment, $\mathrm{t}=$ time, $\mu_{t}=$ error term, DUM_FDI, DUM_ODA, DUM_IBRD are seasonal dummy variables.

\section{RESULT FINDINGS}

We decomposed the WAMZ economy into an internal structure (proxy by RGDP, RGDP per capita) and external structure (proxy by trade robustness, and multilateral trade). We further shocked the system by structural breaks in FDI, ODA, and IBRD which was assumed to have a similar shock pattern with COVID-19.

Tables 2- 6 is a combination of two results Pooled Mean Group (PMG): Panel ARDL and Least Squares Dummy Variables (LSDV). Specifically, Table 4 shows the impact of the structural breakpoints on Real GDP per capita, and Table $\mathbf{7}$ is a comparative analysis of PMG results with and without structural breakpoints. Our focus variables are highlighted in the results presented in Tables 2 - 
Table 3. RGDP = f(FDI, IBRD,DUMV)

\begin{tabular}{|c|c|c|c|c|c|}
\hline \multirow[b]{2}{*}{ Variables } & \multicolumn{2}{|c|}{ PMGWD } & \multicolumn{2}{|c|}{ LSDV } & \multirow[t]{2}{*}{ LSDV intercept } \\
\hline & coeffic. & Prob & coeffic. & Prob & \\
\hline LnFDI & 0.08054 & 0.0033 & 0.058388 & 0.0066 & \\
\hline LnIBRD & 0.007504 & 0.901 & -0.112 & 0.032 & \\
\hline DUM_FDI & 0.007394 & 0.9254 & & & \\
\hline DUM_IBRD & 0.229673 & 0.0016 & & & \\
\hline LnPOP & 1.169061 & 0.0025 & 2.177031 & 0.00001 & \\
\hline $\mathrm{C}$ & 0.058937 & 0.5736 & -3.96084 & 0.00001 & \\
\hline DC2 & & & -1.26377 & 0.00001 & -5.224612 \\
\hline DC3 & & & -2.07222 & 0.00001 & -6.033066 \\
\hline DC4 & & & -0.96234 & 0.00001 & -4.923181 \\
\hline DC5 & & & -0.69212 & 0.00001 & -4.652964 \\
\hline DC6 & & & -0.96304 & 0.00001 & -4.923885 \\
\hline cointeQ01 & -0.230773 & 0.0003 & & & \\
\hline $\mathrm{D}(\mathrm{LnFDI})$ & -0.025109 & 0.0006 & & & \\
\hline $\mathrm{D}($ LnIBRD $)$ & 0.022813 & 0.8564 & & & \\
\hline D(DUM_FDI) & 0.05196 & 0.72101 & & & \\
\hline D(DUM_IBRD) & -0.029261 & 0.3108 & & & \\
\hline $\mathrm{D}(\mathrm{LnPOP})$ & 10.30647 & 0.15401 & & & \\
\hline Adjusted R. & & & 0.95794 & & \\
\hline F-statistic & & & 587.4717 & 0.00001 & \\
\hline
\end{tabular}

where PMGWD: Pooled Mean Group with Dummy Variable LSDV: Least Squares Dummy Variable

Source: Eviews 9

7. There is heterogeneity in WAMZ. The results in Tables 2, 3, 5, and 6 showed that LSDV results are statistically significant. The result obtained from LSDV provides answers to heterogeneity questions in WAMZ.

While the global economy is recovering from the simulated disruption caused by COVID-19, this study took into cognizance past shocks inherent in global capital inflow (a major component of global reinvestment earnings), which has grossly distorted the cross-border financing. Thus, to provide answers to long-run structural breaks (common property of shocks). We studied the impact on past behaviour of global capital inflows shocks on the macroeconomic outlook in the WAMZ. This study incorporated DUM variables e.g. DUM_FDI, DUM_ODA, and DUM_IBRD which formed the basis of shocks and structural breakpoints-calibrated variables. The statistical significance of DUM_FDI, DUM_ODA, and DUM_IBRD would define whether stability or instability exists in WAMZ. This line of reasoning would follow the established $5 \%$ percent hypothetical tests.

Specifically, in Table 2, the cointegrating long-run equation coefficient is well-behaved. Though the outcome is weak at about $28.4 \%$, it is statistically significant. $\mathrm{D}(\mathrm{LnFDI}), \mathrm{D}(\mathrm{LnODA}), \mathrm{D}\left(\mathrm{DUM} \_F D I\right)$, and $\mathrm{D}\left(\mathrm{DU} \mathrm{M}_{-} \mathrm{ODA}\right)$ are short-run variables. In the short-run, instability is found in ODA, but FDI is relatively stable. Conversely, in the long-run, DUM_FDI and DUM_ODA introduce instability in the WAMZ RGDP. Thus, from Table 2, we accept HA.

In Table 3, DUM_FDI and DUM_IBRD represent shock calibrated variables. It could be recalled that dummy variables $(0,1)$ were utilized to account for structural breakpoints in foreign investment inflows. The LSDV results confirmed the existence of heterogeneity in WAMZ. The p-values of DUM_FDI and DUM_IBRD are $0.925>5 \%$ and $0.0016<5 \%$. From the hypothesis, the results imply that there are stability and instability in foreign capital inflows. DUM_FDI brings about stability and DUM_IBRD leads to instability. Thus, foreign investment inflows in the long-run would affect growth through shocks in IBRD. DUM_FDI and DUM_IBRD generate stable in WAMZ's growth. Also, the long-run adjustment from the short-run displayed a well-behaved negative coefficient and is statistically significant.

The coefficient on Table 2, shows that 34.6 percent change in DUM_FDI and 31.6 percent changes in DUM_ODA brings about a positive shock in RGDP and a negative shock in RGDP respectively. In Table 3, DUM_IBRD brings about 22.9 percent positive changes in RGDP as RGDP changes by one percent. This implies that DUM_FDI, DUM_IBRD have a different impact on RGDP in the long-run as compared with the DUM_ODA coefficient to RGDP.

Structural breaks in ODA, IBRD, and FDI inflows in WAMZ represented by DUM_ODA, DUM_IBRD, and DUM_FDI in Table 4, do not affect the stability of Real GDP per capita. Hence, we accept Ho. Unlike, the mixed results in RGDP, RGDDPC in WAMZ are stable in the long-run in the events of structural breaks. The variables in the short-run and the long-run have a coefficient greater than $5 \%$. This implies we accept the Null Hypothesis and reject alternative Hypothesis. The adjustment mechanisms of the short-run to the long-run are not well-behaved. The $p$-values are 0.4693 and 0.8474 (see Table 4).

In Table 4, we observed that one percent change in DUM_FDI, DUM_ODA leads to a decline in RGDP per capita, and DUM_IBRD leads to a rise in RGDP per capita. The result in Tables 2-4 implies that structural breaks impact RDGP more than RGDP per capita. Base on the corresponding P-values which showed varying statistical significances. 
Table 4. Real GDP per capita $=f(F D I, O D A, ~ I B R D, ~ P O P)$

\begin{tabular}{|c|c|c|c|c|c|}
\hline Variables & Coeffic. & Prob. & Variables & Coeffic. & Prob. \\
\hline LNFDI & 2.16123 & 0.9423 & LNFDI & 0.019539 & 0.0335 \\
\hline LNODA & 16.27843 & 0.9433 & LNODA & -0.041529 & 0.1295 \\
\hline DUM_FDI & -5.095538 & 0.9443 & LNIBRD & -0.025222 & 0.07 \\
\hline DUM_ODA & -5.997686 & 0.9432 & LNPOP & -0.007779 & 0.8628 \\
\hline COINTEQ01 & -0.000676 & 0.4693 & COINTEQ01 & -0.090822 & 0.3828 \\
\hline $\mathrm{D}($ LNFDI) & -0.00615 & 0.5672 & $\mathrm{D}$ (LNFDI) & -0.004745 & 0.6115 \\
\hline $\mathrm{D}(\mathrm{LNODA})$ & 0.000457 & 0.977 & $\mathrm{D}($ LNODA $)$ & 0.020246 & 0.0125 \\
\hline D(DUM_FDI) & -0.002895 & 0.7767 & $\mathrm{D}(\mathrm{LNIBRD})$ & 0.007955 & 0.549 \\
\hline D(DUM_ODA) & 0.01137 & 0.517 & $\mathrm{D}$ (LNPOP) & -0.516891 & 0.7834 \\
\hline $\mathrm{C}$ & -0.098638 & 0.4867 & $\mathrm{C}$ & 0.282561 & 0.3744 \\
\hline LNFDI & -0.148836 & 0.9619 & & & \\
\hline LNIBRD & 7.35246 & 0.9534 & & & \\
\hline DUM_FDI & -630.6443 & 0.9775 & & & \\
\hline DUM_IBRD & 630.029 & 0.9775 & & & \\
\hline COINTEQ01 & 0.000177 & 0.8474 & & & \\
\hline $\mathrm{D}$ (LNFDI) & -0.006626 & 0.5299 & & & \\
\hline $\mathrm{D}$ (LNIBRD) & 0.001139 & 0.9804 & & & \\
\hline D(DUM_FDI) & 0.002723 & 0.9476 & & & \\
\hline D(DUM_IBRD) & 0.120088 & 0.8352 & & & \\
\hline $\mathrm{C}$ & 0.009029 & 0.8783 & & & \\
\hline
\end{tabular}

Table 5. Multilateral Trade: $L n M L T=f(L n F D I, L n I B R D$, DUMV $)$

\begin{tabular}{|c|c|c|c|c|c|}
\hline \multirow[b]{2}{*}{ Variables } & \multicolumn{2}{|c|}{ PMGWD } & \multicolumn{2}{|c|}{ LSDV } & \multirow[t]{2}{*}{ LSDV intercept } \\
\hline & coeffic. & Prob & coeffic. & Prob & \\
\hline LnFDI & -0.166267 & 0.0205 & 0.202519 & 0.00001 & \\
\hline LnIBRD & 0.102781 & 0.1142 & 0.320634 & 0.00001 & \\
\hline DUM_FDI & -0.038547 & 0.4488 & & & \\
\hline DUM_IBRD & 0.327504 & 0.00001 & & & \\
\hline \multicolumn{6}{|l|}{ LnPOP } \\
\hline$C$ & 0.290309 & 0.0075 & -2.647674 & 0.00001 & \\
\hline DC2 & & & -0.983093 & 0.00001 & -3.630767 \\
\hline DC3 & & & -1.423668 & 0.00001 & -4.071342 \\
\hline DC4 & & & -0.582096 & 0.00001 & -3.22977 \\
\hline DC5 & & & -1.369743 & 0.00001 & -4.017417 \\
\hline DC6 & & & -0.910369 & 0.00001 & -3.558043 \\
\hline cointeQ01 & -0.348302 & 0.0165 & & & \\
\hline $\mathrm{D}(\mathrm{LnFDI})$ & -0.018594 & 0.5418 & & & \\
\hline $\mathrm{D}($ LnIBRD) & -0.293018 & 0.4002 & & & \\
\hline D(DUM_FDI) & -0.458816 & 0.0844 & & & \\
\hline D(DUM_IBRD) & -0.05501 & 0.6333 & & & \\
\hline @Trend & 0.005581 & 0.0123 & & & \\
\hline Adjusted R. & & & 0.605667 & & \\
\hline F-statistic & & & 48.61375 & 0.00001 & \\
\hline
\end{tabular}

where PMGWD: Pooled Mean Group with Dummy Variable LSDV: Least Squares Dummy Variable

Source: Eviews 9

Also, this paper examined the impact of structural breaks on multilateral trade (MLT) and trade openness (TRB) in Tables 5 and 6. In Table 5, in the long-run, there are mixed results shown by the p-values of DUM_FDI and DUM_IBRD are 0.4488 greater than $5 \%$ and 0.00001 less than 5\%. This implies that DUM_FDI generates stable shocks on MLT while DUM_IBRD causes unstable shock on MLT in WAMZ. The p-values of the short-run D(DUM_FDI) and D(DUM_IBRD) coefficients confirm that shock affects MLT. In Table 5, in concert with Tables 2 and 3, there is the presence of heterogeneity in WAMZ using LSDV. Also, in Table 6, structural breaks affect trade robustness. In other words, trade robustness in WAMZ. DUM_FDI and DUM_ODA are 0.0000 and 0.0219 less than $5 \%$ in the long-run. Thus, we accept the alternative hypothesis and reject the null hypothesis. In the short-run, D(DUM_FDI) causes instability, and D(DUM_IBRD) is stable. A Structural break in foreign investment inflows generates a mixed effect. The speed of adjustments is negative and statistically significant.

One percent rise in FDI and IBRD causes 3.8 percent and 32.7 percent rise and decline in MLT. In the case of trade robustness, FDI and IBRD produced a positive 26.1 percent and 14.3 percent change in MLT. This impact notwithstanding there is a potential amount of risk rises as changes occur in the structure and magnitude of global capital inflows.

Additionally, this paper sought to compare PMG estimator results. Two PMG results include PMG without structural breakpoint incorporated into the model and PMG results with structural breakpoint accounted for using dummy variables. In Table 7, three sets of results were presented which is a summary of results from Tables 2-6 (see section B and C in Table 7). Section A in Table 7 illustrates PMG without a dummy structural break variable. In Table 7, the signs and magnitude are measured. The impact of FDI 
Table 6. Trade Robustness: $\operatorname{LnTRB}=\mathrm{f}(\operatorname{LnFDI}, \operatorname{LnODA}$, DUMV)

\begin{tabular}{|c|c|c|c|c|c|}
\hline \multirow[b]{2}{*}{ Variables } & \multicolumn{2}{|c|}{ PMGWD } & \multicolumn{2}{|c|}{ LSDV } & \multirow[t]{2}{*}{ LSDV intercept } \\
\hline & coeffic. & Prob & coeffic. & Prob & \\
\hline LnFDI & 0.053756 & 0.0081 & 0.096486 & 0.00001 & \\
\hline LnODA & -0.319142 & 0.0000 & 0.038975 & 0.0144 & \\
\hline DUM_FDI & 0.261554 & 0.0000 & & & \\
\hline DUM_ODA & 0.14322 & 0.0219 & & & \\
\hline \multicolumn{6}{|l|}{ LnPOP } \\
\hline $\mathrm{C}$ & 1.120951 & 0.0285 & -1.140853 & 0.0000 & \\
\hline DC2 & & & -0.287669 & 0.0000 & -1.428522 \\
\hline DC3 & & & -0.579995 & 0.0000 & -1.720848 \\
\hline DC4 & & & -0.189926 & 0.0000 & -1.330779 \\
\hline DC5 & & & 0.131672 & 0.0200 & -1.009181 \\
\hline DC6 & & & -0.112994 & 0.0171 & -1.253848 \\
\hline cointeQ01 & -0.281438 & 0.0341 & & & \\
\hline $\mathrm{D}(\mathrm{LnFDI})$ & $5.54 \mathrm{E}-03$ & 0.8957 & & & \\
\hline $\mathrm{D}(\mathrm{LnODA})$ & 0.155888 & 0.0124 & & & \\
\hline D(DUM_FDI) & -0.161825 & 0.00001 & & & \\
\hline D(DUM_ODA) & -0.038396 & 0.1968 & & & \\
\hline Adjusted R. & & & 0.543728 & & \\
\hline F-statistic & & & 36.23953 & 0.0000 & \\
\hline
\end{tabular}

where PMGWD: Pooled Mean Group with Dummy Variable LSDV: Least Squares Dummy Variable

Source: Eviews 9

Table 7. Comparative Analysis: The influence of Structural Breakpoints in PMG

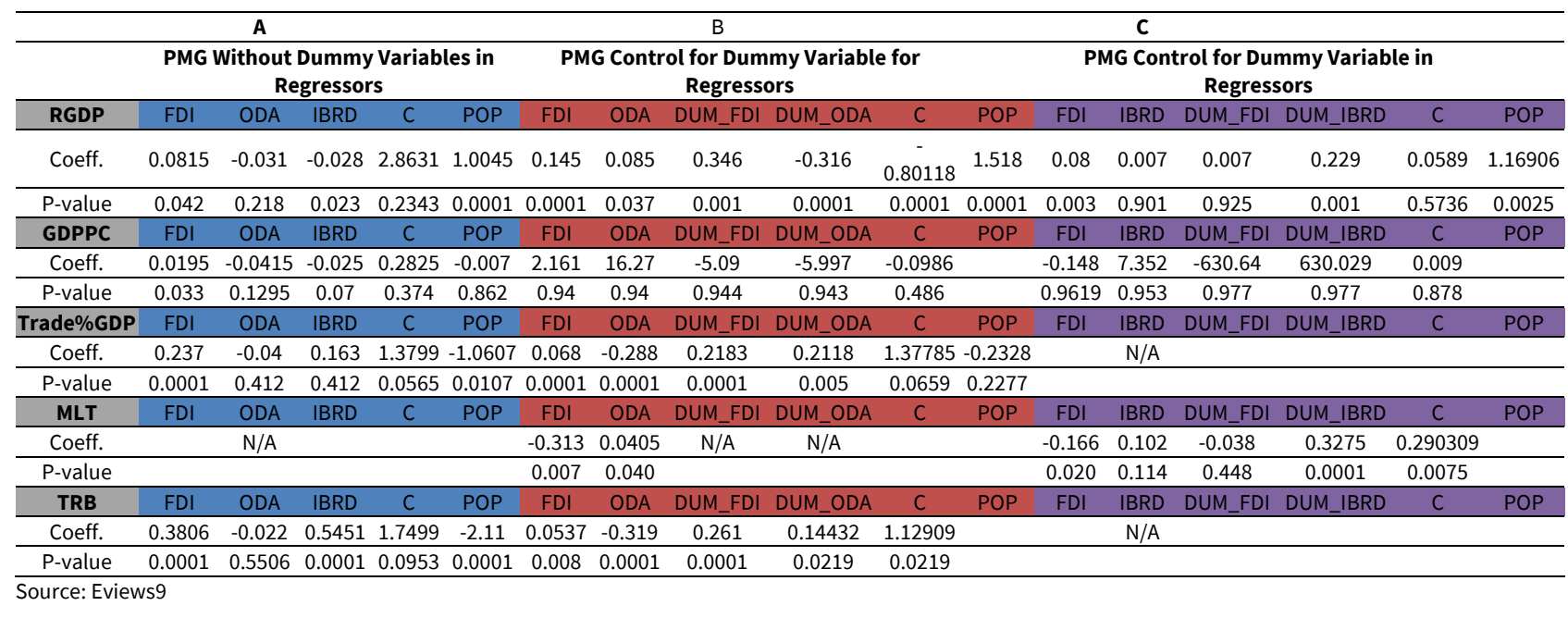

is constant in A, B, and C in Table 7, whereas, the impacts of ODA and IBRD on RGDP showed mixed results. We observed the presence of shocks in the WAMZ system as inherent shocks in global capital inflows affect the stability of the economy. This in turn would further introduce risk exposure in the productive, consumption, and trade pattern of WAMZ thereby crippling already fragile systems. This risk exposure then causes a recession in the WAMZ system. Based on the results which confirmed WAMZ is not insulated from the disruption caused by COVID-19 pandemic hence WAMZ economies would experience recession.

Therefore the implication of the result clearly defined, albeit, not in the entire WAMZ system based on results obtained on the P-values of the shocking variables (DUM_variables) traces of the shock exposure emanating from the vulnerability WAMZ economies are susceptible to. Hence, WAMZ economies are vulnerable to recession based on the fluctuation which COVID 19 had caused on the global reinvestment earning (a key component of foreign capital inflows e.g. FDI) and the consequential adjustments (plummeting effect of global finance) in the inflows of capital for WAMZ to pursue development projects and help WAMZ improve productivity. This shock implies that IMF prediction is perceptible in the WAMZ system in the long-run.

\section{CONCLUSION}

Based on the outcomes of the statistical significance of structural breaks calibrated dummy variables, we conclude that the IMF global prediction of recession is apparent in the long-run. WAMZ would in the long-run become susceptibly exposed and hence experience recession as global capital inflows decline (caused by losses in global reinvested earnings) based on the impact caused by shocks in COVID-19 (health crisis) and the oil price shock (with properties of fluctuation and supply glut). The study found that these shocks would affect WAMZ through supply shocks (decline in productivity, a decline in investment, and decline in Real GDP). 
We observed that the p-value of Dummy Variables (DUM_FDI, DUM_ODA, DUM_IBRD) is statistically significant hence we accept HA in RGDP (see Tables 2 and 3 ).

Conversely, the study found no perceptibly demand shock impact that would bring about a long-run recession. This is because DUM_V (dummy variables) does not have significantt impacts on GDP per capita. Hence, we accept Ho. Basically, based on IMF prediction of a global recession. We could predict from the results that the recent COVID-19 and Oil price shocks would have supply shock in WAMZ. Hence causing the possibility of a two-quarter fall in GDP in WAMZ. Also, the shocks in COVID-19 and Oil price shock would be transmitted to WAMZ through its trade openness policy. Thus, two main drivers of shocks generating recession in WAMZ would be through supply shock and trade openness.

The evidence of structural breaks in foreign assistance provides alternative analysis to underscore the revelation made by Kristalina Georgieva-led IMF prediction on the global recession. This is study is closely consistent with Ogbonnaya and Otta (2018) on the effect of structural breaks in the macroeconomic variables. We found a mix of results. Consequently, WAMZ is not insulated and would be affected by foreign assistance. Breakpoints in foreign assistance produced a significant impact on selected macroeconomic indicators hence implying the susceptibility of WAMZ economies to structural breaks. This implies that the mean of the dependent variables (macroeconomic variables) changes given a one-unit shift in the structural breakpoints variables in foreign capital inflow. Thus, there is heterogeneity in WAMZ and foreign capital causes shocks in WAMZ. Thus, we conclude that WAMZ is susceptible to dynamical changes and fluctuations as a result of shock or disturbance in foreign capital inflow into WAMZ. This study could not agree less that capital from abroad fall (based on the declining performance of global reinvested earning) produces risk exposures in WAMZ. Thus, by extrapolation COVID-19 fluctuation experienced in global capital financing would bring about the predictions by Kristalina Georgieva-led IMF and IMFC on recession in WAMZ.

\section{REFERENCES}

Anyanwu, J. C. and Yameogo, DRND (2015). FDI to Africa: Regional comparison. African Development Review, 345-365, researchgate.net.

Anyanwu, J. C. and Yameogo, N. D. (2014). FDI to Africa: Regional Comparism. Conference paper: International Economic Association World Congress, At King Hussein Bin Talal Convention Center (KHBTCC), in the Dead Sea, Jordan.

Bai, J. and Perron, P. (1998). Estimating and testing linear models with multiple structural change. Econometrica, 66(1), 47-78. https://doi.org/10.2307/2998540

Bai, J. and Perron, P. (2003). Critical values for multiple structural change tests. Econometric Journal, 6(1), $672-678$. https://doi.org/10.1111/1368-423X.00102

Baltagi, B. H, Feng, Q. and Kao, C. (2015). Estimation of heterogeneous panels with structural breaks. Journal of Econometrics, 191(1), 176-195. https://doi.org/10.1016/j.jeconom.2015.03.048

Byrne, J. P. and Perman, R. (2006). Unit roots and structural breaks: A survey of the literature. Working Papers 2006_10, Business School - Economics, University of Glasgow. media_219103_s.

Chang, S. Y. and Perron, P. (2017). Fractional unit root tests allowing for a structural change in trend under both the Null and Alternative hypothesis. Econometrics, 5(11), 77-102. https://doi.org/10.3390/econometrics5010005

Cho, C-K. and Vogelsang, T. J. (2017). Fixed- $b$ inferences for testing structural change in a time series regression. Econometrics, 5(11), 4-29. https://doi.org/10.3390/econometrics5010002

Chow, G. C. (1960). Tests of equality between sets of coefficients in two linear. Econometrica, 28(3), 591-605. https://doi.org/10.2307/1910133

Clemente, J., Gadea, M. D., Montanes, A. and Reyes, M. (2017). Structural breaks, inflation and interest rates: Evidence from the G7 countries. Econometrics, 5(11), 141-157. https://doi.org/10.3390/econometrics5010011

Gadea, M. D., Gomez-Loscos, A. and Montanes, A. (2017). Oil price and economic grwoth: A long story? Econometrics, 5(11), 113140. https://doi.org/doi:10.3390/econometrics4040041

Glynn, J., Perera, N. and Verma, R. (2007). Unit root tests and structural breaks: a survey with applications. Revista de Metodos Cuantitativos para la Economia y la Empresa=Journal of Quantitative Methods for Economics and Business Administration, 3(1), 63-79. research-pubs@uow.edu.au.

Kapetanois, G. and Tzavalis, E. (2007). Modelling Structural Breaks in economic relationships using large shocks. modeling_struct. Conference paper of 2005 SNDE conference in London and 2006 workshop on Nonlinearities in Economics and Finance at Cambridge.

Leybourne, S. and Newbold, P. (2003). Spurious rejections by cointegration tests induced by structural breaks. Applied Economics, 35(9), 1117-1121. https://doi.org/10.1080/0203684032000082068

Lumsdaine, R. and Papell, D. (1997). Multiple trends breaks and the unit root hypothesis. Review of Economics and Statistics, 79(1), 212-218. https://doi.org/10.1162/003465397556791

McKinnon, R. I. (1973). Money and Capital in Economic Development, Brookings Institution, Washington D.C.

Nejad, K. M., Jahantigh, F. and Rahbari, H. (2016). The long-run relationship between oil price risk and Tehran stock exchange returns in presence of structural breaks. Elsevier Procedia Economics and Finance, 36, 201-2019. https://doi.org/10.1016/S22125671(16)30031-4 
Ogbonnaya, I. O. and Otta, N. N. (2018). Structural breaks in Nigeria's macroeconomic time series data. Journal of Economics and Sustainable Development, ISSN 2222-1700 (paper), ISSN 2222-2855 (online), 9(11), 1-8. ISSN 2222-1700 (paper), ISSN 2222-2855 (online).

Omotor, D. G. (2011). Structural breaks, demand for money and monetary policy in Nigeria. Ekonomski Pregled, 62(9-10), 559-582. UDK 336.741.237.1:336.711

Perron, P. (1989). The great crash, the oil price shock, and the unit root hypothesis. Econometrica, 57(6), $1361-1401$. https://doi.org/10.2307/1913712

Perron, P. (1997). Further evidence on breaking trend functions in macroeconomic variables. Journal of Econometrics, 80(2), 355385. https://doi.org/10.1016/S0304-4076(97)00049-3

Perron, P. and Vogelsang, T. V. (1992). Nonstationarity and level shifts with an application to purchasing power parity. Journal of Business and Economics Statistics, 10(3), 301-320. https://doi.org/10.1080/07350015.1992.10509907

Raheem, I. D. and Olabisi, N. O. (2018). What is new? The role of asymmetry and breaks in oil price-output growth volatility nexus. OPEC Energy Review, 43(1), 1-13. https://doi.org/10.1111/opec.12142

Sengupta, A. (2017). Testing for a structural break in a spatial panel method. Perron P. (ed.) Unit roots and structural Breaks. Econometrics, 5(11), 50-66. https://doi.org/10.3390/econometrics5010012

Shaw, E. S. (1973). Financial Deepening in Economic Development. New York: Oxford University Press.

Summers, L. H. (2000). International financial crises: causes, prevention, and cures. America Economic Review, 90(2), 1-16. https://doi.org/10.1257/aer.90.2.1

UNCTAD (2020) World Investment Report. Available at: https://untad.org

Westerlund, J. (2006). Testing for panel ointegartion with multiple structural breaks. Oxford Bulletin of Economics and Statistics, 68(1), 101-132. https://doi.org/10.1111/j.1468-0084.2006.00154.x

Worldometer (2020). Coronavirus update. Available at: https://www.worldometers.info/coronavirus/

Yang, J. (2017). Consistency of trend break point estimator with underspecified break number. Econometrics, 5(11), 30-49. https://doi.org/10.3390/econometrics501004

Zivot, E. and Andrews, D. W. K. (1992). Further evidence on the great crash, the oil price shock, and the unit root hypothesis. Journal of Business and Economics Statistics, 10(3), 251-270. https://doi.org/10.2307/1391541

\section{DESCRIPTIVE ANALYSIS}

\section{The GAMBIA}

\begin{tabular}{cccccccccc}
\hline & RGDP & GDP & FDI & ODA & IBRD & MLT & TRD & TRB & POP \\
\hline Mean & $1.20 \mathrm{E}+10$ & $5.71 \mathrm{E}+08$ & 22053873 & $1.05 \mathrm{E}+08$ & 89878304 & 27.84456 & 76.90266 & 0.769027 & 1090856. \\
\hline Median & $1.13 \mathrm{E}+10$ & $6.01 \mathrm{E}+08$ & 11365906 & 99095000 & 64176500 & 17.03721 & 72.74072 & 0.727407 & 1022594. \\
\hline Maximum & $2.41 \mathrm{E}+10$ & $1.49 \mathrm{E}+09$ & 82208103 & $2.66 \mathrm{E}+08$ & $2.63 \mathrm{E}+08$ & 87.86628 & 131.4854 & 1.314854 & 2100568. \\
\hline Minimum & $1.06 \mathrm{E}+09$ & 52296837 & -1990000. & 10480000 & 0.000000 & 1.212310 & 44.07639 & 0.440764 & 447285.0 \\
\hline Std. Dev. & $6.01 \mathrm{E}+09$ & $4.12 \mathrm{E}+08$ & 24965678 & 54142190 & 77540943 & 27.20252 & 23.24968 & 0.232497 & 492707.1 \\
\hline Skewness & 0.328923 & 0.520642 & 0.995875 & 0.688680 & 0.639010 & 1.003776 & 0.459088 & 0.459088 & 0.446575 \\
\hline Kurtosis & 2.227075 & 2.347003 & 2.814198 & 3.563182 & 2.244806 & 2.677763 & 2.198829 & 2.198829 & 2.022822 \\
\hline \hline Jarque-Bera & 2.060351 & 3.021358 & 6.335847 & 4.428589 & 4.407309 & 8.268205 & 2.969846 & 2.969846 & 3.505187 \\
\hline Probability & 0.356944 & 0.220760 & 0.042091 & 0.109231 & 0.110399 & 0.016017 & 0.226520 & 0.226520 & 0.173324 \\
\hline \hline Sum & $5.75 \mathrm{E}+11$ & $2.74 \mathrm{E}+10$ & $8.38 \mathrm{E}+08$ & $5.05 \mathrm{E}+09$ & $4.31 \mathrm{E}+09$ & 1336.539 & 3691.328 & 36.91328 & 52361075 \\
\hline Sum Sq. Dev. & $1.70 \mathrm{E}+21$ & $7.99 \mathrm{E}+18$ & $2.31 \mathrm{E}+16$ & $1.38 \mathrm{E}+17$ & $2.83 \mathrm{E}+17$ & 34778.93 & 25405.74 & 2.540574 & $1.14 \mathrm{E}+13$ \\
\hline \hline Observations & 48 & 48 & 38 & 48 & 48 & 48 & 48 & 48 & 48 \\
\hline & & & & & & & & 48 \\
\hline
\end{tabular}


GHANA

\begin{tabular}{|c|c|c|c|c|c|c|c|c|c|}
\hline & RGDP & GDP & FDI & ODA & IBRD & MLT & TRD & TRB & POP \\
\hline Mean & $1.81 \mathrm{E}+10$ & $.41 \mathrm{E}+10$ & $8.08 \mathrm{E}+08$ & $9.16 \mathrm{E}+08$ & $1.65 E+09$ & 13.94372 & 56.23146 & 0.562315 & 16946225 \\
\hline Median & $1.35 \mathrm{E}+10$ & $5.93 E+09$ & $1.07 \mathrm{E}+08$ & $8.69 \mathrm{E}+08$ & $1.50 \mathrm{E}+09$ & 7.671294 & 57.04611 & 0.570461 & 16113303 \\
\hline Maximum & $4.82 \mathrm{E}+10$ & $6.33 \mathrm{E}+10$ & $3.49 \mathrm{E}+09$ & $1.97 \mathrm{E}+09$ & $4.31 \mathrm{E}+09$ & 62.93133 & 116.0484 & 1.160484 & 28833629 \\
\hline Minimum & 1755.605 & $2.11 \mathrm{E}+09$ & -18260970 & $1.57 \mathrm{E}+08$ & 53337000 & 0.366625 & 6.320343 & 0.063203 & 8596983. \\
\hline Std. Dev. & $1.16 \mathrm{E}+10$ & $1.74 \mathrm{E}+10$ & $1.29 \mathrm{E}+09$ & $4.94 \mathrm{E}+08$ & $1.37 \mathrm{E}+09$ & 17.23579 & 28.53759 & 0.285376 & 6107027. \\
\hline Skewness & 1.232603 & 1.648953 & 1.244749 & 0.318684 & 0.342710 & 1.554443 & 0.160434 & 0.160434 & 0.371234 \\
\hline Kurtosis & 3.573724 & 4.322276 & 2.704098 & 2.132190 & 1.777635 & 4.187566 & 2.111126 & 2.111126 & 1.912530 \\
\hline Jarque-Bera & 12.81280 & 25.24921 & 11.26092 & 2.318663 & 3.927952 & 22.15096 & 1.786107 & 1.786107 & 3.467701 \\
\hline Probability & 0.001651 & 0.000003 & 0.003587 & 0.313696 & 0.140299 & 0.000015 & 0.409404 & 0.409404 & 0.176603 \\
\hline Sum & $8.67 \mathrm{E}+11$ & $6.78 \mathrm{E}+11$ & $3.47 \mathrm{E}+10$ & $4.40 \mathrm{E}+10$ & $7.90 \mathrm{E}+10$ & 669.2985 & 2699.110 & 26.99110 & $8.13 E+08$ \\
\hline Sum Sq. Dev. & $6.37 \mathrm{E}+21$ & $1.42 \mathrm{E}+22$ & $7.00 \mathrm{E}+19$ & $1.15 \mathrm{E}+19$ & $8.82 \mathrm{E}+19$ & 13962.40 & 38276.51 & 3.827651 & $1.75 \mathrm{E}+15$ \\
\hline Observations & 48 & 48 & 43 & 48 & 48 & 48 & 48 & 48 & 48 \\
\hline
\end{tabular}

NIGERIA

\begin{tabular}{cccccccccc}
\hline & RGDP & GDP & ODA & FDI & IBRD & TRD & MLT & TRB & POP \\
\hline Mean & $2.06 \mathrm{E}+11$ & $1.45 \mathrm{E}+11$ & $1.03 \mathrm{E}+09$ & $2.15 \mathrm{E}+09$ & $2.44 \mathrm{E}+09$ & 33.27361 & 6.441065 & 0.332736 & $1.10 \mathrm{E}+08$ \\
\hline Median & $1.50 \mathrm{E}+11$ & $6.18 \mathrm{E}+10$ & $3.15 \mathrm{E}+08$ & $1.07 \mathrm{E}+09$ & $2.29 \mathrm{E}+09$ & 35.25827 & 7.064414 & 0.352583 & $1.04 \mathrm{E}+08$ \\
\hline Maximum & $4.64 \mathrm{E}+11$ & $5.68 \mathrm{E}+11$ & $1.29 \mathrm{E}+10$ & $8.84 \mathrm{E}+09$ & $7.91 \mathrm{E}+09$ & 53.27796 & 12.52967 & 0.532780 & $1.91 \mathrm{E}+08$ \\
\hline Minimum & $9.52 \mathrm{E}+10$ & $9.18 \mathrm{E}+09$ & 13.43188 & $-7.39 \mathrm{E}+08$ & $1.82 \mathrm{E}+08$ & 9.135846 & 0.863391 & 0.091358 & 55981400 \\
\hline Std. Dev. & $1.14 \mathrm{E}+11$ & $1.58 \mathrm{E}+11$ & $2.14 \mathrm{E}+09$ & $2.52 \mathrm{E}+09$ & $1.84 \mathrm{E}+09$ & 12.28075 & 3.392712 & 0.122808 & 39548062 \\
\hline Skewness & 1.192779 & 1.320292 & 4.208361 & 1.330121 & 0.895736 & -0.438576 & -0.116541 & -0.438576 & 0.421257 \\
\hline Kurtosis & 2.980633 & 3.378216 & 22.05178 & 3.607575 & 3.598044 & 2.187816 & 1.804755 & 2.187816 & 2.026850 \\
\hline \hline Jarque-Bera & 11.38253 & 14.23145 & 867.6229 & 14.89208 & 7.134059 & 2.858075 & 2.904089 & 2.858075 & 3.313703 \\
\hline Probability & 0.003375 & 0.000812 & 0.000000 & 0.000584 & 0.028240 & 0.239539 & 0.234091 & 0.239539 & 0.190739 \\
\hline \hline Sum & $9.88 \mathrm{E}+12$ & $6.94 \mathrm{E}+12$ & $4.93 \mathrm{E}+10$ & $1.03 \mathrm{E}+11$ & $1.17 \mathrm{E}+11$ & 1597.133 & 302.7300 & 15.97133 & $5.30 \mathrm{E}+09$ \\
\hline Sum Sq. Dev. & $6.12 \mathrm{E}+23$ & $1.17 \mathrm{E}+24$ & $2.16 \mathrm{E}+20$ & $2.98 \mathrm{E}+20$ & $1.59 \mathrm{E}+20$ & 7088.391 & 529.4826 & 0.708839 & $7.35 \mathrm{E}+16$ \\
\hline \hline Observations & 48 & 48 & 48 & 48 & 48 & 48 & 47 & 48 & 48 \\
\hline
\end{tabular}

\section{SIERRA LEONE}

\begin{tabular}{|c|c|c|c|c|c|c|c|c|c|}
\hline & RGDP & GDP & FDI & ODA & IBRD & TRD & MLT & TRB & POP \\
\hline Mean & $1.92 \mathrm{E}+09$ & $1.48 \mathrm{E}+09$ & 95478104 & $2.98 \mathrm{E}+08$ & $1.75 \mathrm{E}+08$ & 51.84245 & 13.96661 & 0.518425 & 4618017. \\
\hline Median & $1.72 \mathrm{E}+09$ & $9.78 \mathrm{E}+08$ & 9225396. & $2.09 \mathrm{E}+08$ & $1.10 \mathrm{E}+08$ & 48.81900 & 12.30103 & 0.488190 & 4306377. \\
\hline Maximum & $3.99 \mathrm{E}+09$ & $5.02 \mathrm{E}+09$ & $9.50 \mathrm{E}+08$ & $1.04 \mathrm{E}+09$ & $5.91 \mathrm{E}+08$ & 93.27412 & 46.99417 & 0.932741 & 7557212. \\
\hline Minimum & $1.29 \mathrm{E}+09$ & $4.20 \mathrm{E}+08$ & $-1.40 \mathrm{E}+08$ & 41510000 & 6327000. & 23.02986 & 0.979846 & 0.230299 & 2692259. \\
\hline Std. Dev. & $7.17 \mathrm{E}+08$ & $1.21 \mathrm{E}+09$ & $2.10 \mathrm{E}+08$ & $2.25 \mathrm{E}+08$ & $1.62 \mathrm{E}+08$ & 16.14078 & 13.48793 & 0.161408 & 1412142. \\
\hline Skewness & 1.569527 & 1.588050 & 2.477337 & 1.214653 & 1.118509 & 0.634087 & 0.839185 & 0.634087 & 0.583992 \\
\hline Kurtosis & 4.460521 & 4.469894 & 8.776270 & 4.423556 & 3.355733 & 2.983955 & 2.653321 & 2.983955 & 2.208878 \\
\hline Jarque-Bera & 23.97356 & 24.49640 & 115.8282 & 15.85607 & 10.26160 & 3.217045 & 3.671387 & 3.217045 & 3.980123 \\
\hline Probability & 0.000006 & 0.000005 & 0.000000 & 0.000360 & 0.005912 & 0.200183 & 0.159503 & 0.200183 & 0.136687 \\
\hline Sum & $9.23 \mathrm{E}+10$ & $7.13 \mathrm{E}+10$ & $4.58 \mathrm{E}+09$ & $1.43 \mathrm{E}+10$ & $8.40 \mathrm{E}+09$ & 2488.438 & 418.9983 & 24.88438 & $2.22 \mathrm{E}+08$ \\
\hline Sum Sq. Dev. & $2.42 \mathrm{E}+19$ & $6.91 \mathrm{E}+19$ & $2.08 \mathrm{E}+18$ & $2.39 \mathrm{E}+18$ & $1.24 \mathrm{E}+18$ & 12244.66 & 5275.806 & 1.224466 & $9.37 \mathrm{E}+13$ \\
\hline Observations & 48 & 48 & 48 & 48 & 48 & 48 & 30 & 48 & 48 \\
\hline
\end{tabular}


LIBERIA

\begin{tabular}{|c|c|c|c|c|c|c|c|c|c|}
\hline & RGDP & GDP & FDI & ODA & IBRD & TRD & MLT & TRB & POP \\
\hline Mean & $1.98 \mathrm{E}+09$ & $1.91 \mathrm{E}+09$ & $2.90 \mathrm{E}+08$ & $2.99 \mathrm{E}+08$ & $1.54 \mathrm{E}+08$ & 150.4613 & 1.757922 & 1.504613 & 2641587. \\
\hline Median & $1.88 \mathrm{E}+09$ & $1.75 \mathrm{E}+09$ & 82986056 & $1.75 \mathrm{E}+08$ & $1.70 \mathrm{E}+08$ & 122.5782 & 2.016037 & 1.225782 & 2191101. \\
\hline Maximum & $2.58 \mathrm{E}+09$ & $3.29 E+09$ & $2.31 E+09$ & $1.31 \mathrm{E}+09$ & $3.06 \mathrm{E}+08$ & 311.3541 & 2.657290 & 3.113541 & 4731906. \\
\hline Minimum & $1.31 \mathrm{E}+09$ & $7.48 \mathrm{E}+08$ & $-1.32 \mathrm{E}+08$ & 44190000 & 0.000000 & 65.39155 & 0.081466 & 0.653915 & 1416529. \\
\hline Std. Dev. & $4.48 \mathrm{E}+08$ & $9.84 \mathrm{E}+08$ & $5.76 \mathrm{E}+08$ & $3.21 \mathrm{E}+08$ & 98748148 & 80.57838 & 0.901719 & 0.805784 & 976813.4 \\
\hline Skewness & 0.068507 & 0.261544 & 2.715354 & 1.787054 & -0.215286 & 0.967105 & -0.328874 & 0.967105 & 0.726568 \\
\hline Kurtosis & 1.671776 & 1.436101 & 9.027086 & 5.210045 & 1.426400 & 2.505179 & 1.604858 & 2.505179 & 2.243424 \\
\hline Jarque-Bera & 1.337214 & 2.039550 & 131.6367 & 35.31710 & 5.323215 & 2.989511 & 4.658983 & 2.989511 & 5.368018 \\
\hline Probability & 0.512422 & 0.360676 & 0.000000 & 0.000000 & 0.069836 & 0.224303 & 0.097345 & 0.224303 & 0.068289 \\
\hline Sum & $3.56 \mathrm{E}+10$ & $3.44 \mathrm{E}+10$ & $1.39 \mathrm{E}+10$ & $1.44 \mathrm{E}+10$ & $7.37 \mathrm{E}+09$ & 2708.304 & 82.62232 & 27.08304 & $1.27 \mathrm{E}+08$ \\
\hline Sum Sq. Dev. & $3.41 \mathrm{E}+18$ & $1.64 \mathrm{E}+19$ & $1.56 \mathrm{E}+19$ & $4.85 \mathrm{E}+18$ & $4.58 \mathrm{E}+17$ & 110378.9 & 37.40248 & 11.03789 & $4.48 \mathrm{E}+13$ \\
\hline Observations & 18 & 18 & 48 & 48 & 48 & 18 & 47 & 18 & 48 \\
\hline
\end{tabular}

GUINEA

\begin{tabular}{|c|c|c|c|c|c|c|c|c|c|}
\hline & RGDP & GDP & FDI & ODA & IBRD & MLT & TRD & DOPX & POP \\
\hline Mean & $5.58 \mathrm{E}+09$ & $4.76 \mathrm{E}+09$ & $1.65 \mathrm{E}+08$ & $3.02 \mathrm{E}+08$ & $5.33 \mathrm{E}+08$ & 6.931439 & 65.45242 & 0.654524 & 7486140. \\
\hline Median & $5.37 \mathrm{E}+09$ & $3.63 E+09$ & 18775000 & $2.99 \mathrm{E}+08$ & $2.93 \mathrm{E}+08$ & 5.235143 & 60.89802 & 0.608980 & 7353764. \\
\hline Maximum & $1.05 \mathrm{E}+10$ & $1.05 \mathrm{E}+10$ & $1.62 \mathrm{E}+09$ & $5.74 \mathrm{E}+08$ & $1.31 \mathrm{E}+09$ & 22.82524 & 146.7666 & 1.467666 & 12717176 \\
\hline Minimum & $2.89 E+09$ & $1.92 \mathrm{E}+09$ & -73758604 & 23380000 & 20405000 & 0.644217 & 42.41507 & 0.424151 & 4219770. \\
\hline Std. Dev. & $1.98 \mathrm{E}+09$ & $2.44 \mathrm{E}+09$ & $3.47 \mathrm{E}+08$ & $1.66 \mathrm{E}+08$ & $4.71 \mathrm{E}+08$ & 5.346803 & 20.95008 & 0.209501 & 2772960. \\
\hline Skewness & 0.638187 & 0.820702 & 2.877191 & 0.014986 & 0.472432 & 1.721232 & 2.122978 & 2.122978 & 0.296494 \\
\hline Kurtosis & 2.678043 & 2.296522 & 8177 & 1.883373 & 1.549785 & 5.177422 & 8.572027 & 8.572027 & 1.679122 \\
\hline Jarque-Bera & 2.310381 & 4.252122 & 137.8226 & 2.495510 & 5.991780 & 26.27022 & 65.43417 & 65.43417 & 4.192705 \\
\hline Probability & 0.314997 & 0.119306 & 0.000000 & 0.287149 & 0.049992 & 0.000002 & 0.000000 & 0.000000 & 0.122904 \\
\hline Sum & $1.78 \mathrm{E}+11$ & $1.52 \mathrm{E}+11$ & $5.27 \mathrm{E}+09$ & $1.45 \mathrm{E}+10$ & $2.56 \mathrm{E}+10$ & 263.3947 & 2094.478 & 20.94478 & $3.59 \mathrm{E}+08$ \\
\hline Sum Sq. Dev. & $1.22 \mathrm{E}+20$ & $1.84 \mathrm{E}+20$ & $3.73 \mathrm{E}+18$ & $1.29 \mathrm{E}+18$ & $1.04 \mathrm{E}+19$ & 1057.767 & 13606.08 & 1.360608 & $3.61 \mathrm{E}+14$ \\
\hline Observations & 32 & 32 & 32 & 48 & 48 & 38 & 32 & 32 & 48 \\
\hline
\end{tabular}

POOLED DESCRIPTIVE

\begin{tabular}{|c|c|c|c|c|c|c|c|c|c|}
\hline & RGDP & GDP & FDI & ODA & IBRD & MEW & TRD & TRB & POP \\
\hline Mean & $4.81 \mathrm{E}+10$ & $3.27 \mathrm{E}+10$ & $6.33 \mathrm{E}+08$ & $4.91 \mathrm{E}+08$ & $8.39 \mathrm{E}+08$ & 11.91311 & 63.13550 & 0.631355 & 23864540 \\
\hline Median & $9.22 \mathrm{E}+09$ & $3.11 E+09$ & 58930000 & $2.47 \mathrm{E}+08$ & $2.33 E+08$ & 5.644637 & 54.23664 & 0.542366 & 5020992. \\
\hline Maximum & $4.64 \mathrm{E}+11$ & $5.68 \mathrm{E}+11$ & $8.84 \mathrm{E}+09$ & $1.29 \mathrm{E}+10$ & $7.91 \mathrm{E}+09$ & 87.86628 & 311.3541 & 3.113541 & $1.91 \mathrm{E}+08$ \\
\hline Minimum & 1755.605 & 52296837 & $-7.39 E+08$ & 13.43188 & 0.000000 & 0.081466 & 6.320343 & 0.063203 & 447285.0 \\
\hline Std. Dev. & $9.38 \mathrm{E}+10$ & $8.97 \mathrm{E}+10$ & $1.45 \mathrm{E}+09$ & $9.71 \mathrm{E}+08$ & $1.30 \mathrm{E}+09$ & 17.12242 & 40.98106 & 0.409811 & 42349240 \\
\hline Skewness & 2.761788 & 4.008603 & 3.358326 & 8.735729 & 2.252516 & 2.535898 & 2.927030 & 2.927030 & 2.286383 \\
\hline Kurtosis & 10.62109 & 19.28429 & 15.29343 & 101.7719 & 8.592074 & 9.437884 & 16.26529 & 16.26529 & 7.258488 \\
\hline Jarque-Bera & 893.2924 & 3321.990 & 2101.423 & 120733.7 & 618.7993 & 722.0718 & 2119.900 & 2119.900 & 468.5390 \\
\hline Probability & 0.000000 & 0.000000 & 0.000000 & 0.000000 & 0.000000 & 0.000000 & 0.000000 & 0.000000 & 0.000000 \\
\hline Sum & $1.16 \mathrm{E}+13$ & $7.90 \mathrm{E}+12$ & $1.63 \mathrm{E}+11$ & $1.41 \mathrm{E}+11$ & $2.42 \mathrm{E}+11$ & 3073.583 & 15278.79 & 152.7879 & $6.87 \mathrm{E}+09$ \\
\hline Sum Sq. Dev. & $2.12 \mathrm{E}+24$ & $1.94 \mathrm{E}+24$ & $5.42 \mathrm{E}+20$ & $2.71 \mathrm{E}+20$ & $4.89 \mathrm{E}+20$ & 75346.54 & 404746.8 & 40.47468 & $5.15 \mathrm{E}+17$ \\
\hline Observations & 242 & 242 & 257 & 288 & 288 & 258 & 242 & 242 & 288 \\
\hline
\end{tabular}

